\title{
EATS: a life cycle-based decision support tool for local authorities and school caterers
}

\author{
Valeria De Laurentiis ${ }^{1}$ (1) $\cdot$ Dexter V. L. Hunt ${ }^{1} \cdot$ Susan E. Lee ${ }^{1} \cdot$ Christopher D. F. Rogers $^{1}$
}

Received: 2 May 2017 / Accepted: 27 February 2018 / Published online: 16 March 2018

(C) The Author(s) 2018

\begin{abstract}
Purpose This paper describes the research that underpins the development of EATS (the Environmental Assessment Tool for School meals), a life cycle-based decision support tool for local authorities and their contractors responsible for providing catering services to schools. The purpose of this tool is to quantify the carbon footprint (CF) and water footprint (WF) of the meals served in order to identify hotspot meals and ingredients, and suggest simple, yet transformative, reduction measures. A case study is used to test the tool, comparing the impacts of 34 school meal recipes.

Methods The tool utilises secondary data to calculate values of CF and WF for a school meal from cradle to plate. This includes three phases: (1) food production, (2) transport of each ingredient to a generic school kitchen in the UK, and (3) meal preparation. Considerations for waste along the supply chain are included. After testing the tool against a set of nutritionally compliant meals, a sensitivity analysis was performed to investigate the influence of the origin and seasonality of the ingredients, transport mode and cooking appliances used on the final results.

Results and discussion The results of the case study show the predominance of the production phase in the overall carbon footprint and that there is a strong tendency towards lower impacts for meat-free meals; however, this is not always the case, for instance some of the chicken-based meals present lower impacts than vegetarian meals rich in dairy ingredients. The sensitivity analysis performed on one of the meals shows that the highest value of $\mathrm{CF}$ is obtained when the horticultural products are out of season and produced in heated greenhouses, whilst the highest value of WF is obtained when the origin of the ingredients is unknown and the global average values of WF are used in the analysis; this defines a crucial data need if accurate analyses are to be uniformly possible.

Conclusions This article focuses on the potential offered by the public food sector for a transformative reduction in the environmental impact of urban food consumption. The results presented prove that careful menu planning and procurement choices can considerably reduce the overall environmental impact of the service provided without compromising quality or variety. This research thus supports those responsible for making these decisions via a user-friendly tool based on robust scientific evidence.
\end{abstract}

Keywords Carbon footprint $\cdot$ Food systems $\cdot$ Public procurement $\cdot$ School meals $\cdot$ Sustainable diets $\cdot$ Water footprint

\section{Introduction}

Responsible editor: Giuseppe Ioppolo

Electronic supplementary material The online version of this article (https://doi.org/10.1007/s11367-018-1460-x) contains supplementary material, which is available to authorized users.

Valeria De Laurentiis

VXD317@bham.ac.uk

1 Civil Engineering/College of Engineering and Physical Sciences, University of Birmingham, Birmingham B15 2TT, UK
Food supplies to a city are critical for its survival. They are a vital resource flow, which, together with water and energy, determine the healthy operation of the city and its people. Indeed, to understand how a city functions, it is important to understand its resource flows, and their interactions and management, to determine how an intervention to one flow would impact on another and its repercussions for city life (Lee et al. 2016).

Cities are putting increasing strains on their natural resources as they grow and develop. Populations are increasing, and in 2008, more than half the world's population (3.3 
billion) were living in urban areas (UNFPA 2014). Cities therefore have a huge influence on resource demands now and, especially, in the future, with $70 \%$ of the global population (nine billion people) expected to live in them by 2050 (OECD 2012). At the same time as the climate changes, pressures are exerted not only on food-producing areas but on urban areas that need a ready food supply, no matter what the weather conditions. Furthermore, many countries are becoming increasingly aware of the need to reduce their carbon emissions, as shown by the Kyoto protocol (UNFCCC 1997) highlighting the need for targets to tackle such emissions. Certain cities (e.g. Oxford, Birmingham, Copenhagen, Rio de Janeiro, Seoul, Johannesburg, Antwerp, Seattle) are taking the lead by setting their own more stringent targets and putting in place initiatives to achieve them. Nevertheless, the way emissions are accounted for can significantly influence the choice of initiatives set to meet carbon reduction targets.

Traditional methods of accounting for greenhouse gas emissions of countries, regions and cities have been based on activities occurring inside their geographical boundaries. This implied the exclusion of emissions produced in upstream processes located outside their borders and caused by the production of goods and services consumed by the population living within them (Larsen and Hertwich 2009). At a national level, this approach (referred to as territorial-based or production-based accounting) has been criticised for failing to account for a phenomenon known as carbon leakage (Peters and Hertwich 2007). This happens when highincome countries, due to international trade, are able to partially externalise their environmental impacts, and therefore an apparent reduction of emissions at a national level is offset by an increase outside their jurisdiction (Blanco et al. 2014; Peters et al. 2011). In the field of water resource management, a similar phenomenon has been defined through the concept of virtual water trade, represented by virtual water embedded in goods imported through international trade (Hoekstra 2003). As both climate change and resource use are driven by consumption, some authors have suggested the idea of accounting for them from a consumption perspective rather than a production perspective (Munksgaard and Pedersen 2001; Peters 2008; Peters and Hertwich 2007; van Oel et al. 2009; Wood et al. 2014).

The limitations of a territorial-based approach also apply to cities, as most of the resources consumed therein (and the related greenhouse gas emissions) originate from outside cities boundaries (Dodman 2009; Larsen and Hertwich 2009; Ramaswami et al. 2008; Vanham et al. 2016). The inclusion of embedded emissions and resources used in the production and delivery of goods and services consumed within a city has wide implications for strategies set to meet carbon reduction targets and improve the environmental sustainability of cities. Under a consumption-based accounting approach, measures would include a focus on influencing consumers towards sustainable purchasing choices or promoting material recycling and conservation through, for instance, information campaigns (Erickson et al. 2013; Munksgaard and Pedersen 2001; Ramaswami et al. 2008), alongside more traditional (and yet very important) strategies such as improving the energy efficiency of the building stock, improving the public transport system, and improving the efficiency of both urban water management and waste management.

Food consumption is a key example of the importance of accounting for consumption-based resource use and emissions in cities. A study by Vanham et al. (2016), based in 13 Mediterranean cities, found that the water footprint (WF) related to food consumption of city dwellers was about 30 times higher than their direct urban water use. In separate studies conducted for the cities of London and Oxford (UK) and San Francisco (US), authors calculated the greenhouse gas emissions from a consumption-based approach and found that food consumption accounted for approximately $20 \%$ of the total emissions in all cases (Low Carbon Oxford 2012; Riddlestone and Plowman 2009; San Francisco Department of the Environment 2013). In the case of London, this value was comparable to emissions arising from household energy use $(22 \%)$ and private transport (20\%). As these impacts vary significantly according to the dietary choices and the amount of food wasted by cities' inhabitants, some cities have started to actively promote low impact diets and food waste reduction in their climate action planning (Erickson et al. 2013; Vanham et al. 2016). One example is provided by the City of San Francisco, the first city in the USA to introduce a resolution to adopt meat-free Mondays. Similarly, the City of Portland aims by 2020 to introduce food waste prevention campaigns, policies that encourage the purchase of low carbon food for public meetings and events and that leverage the purchasing power of public and private institutions to source low carbon food and educate citizens on low carbon food choices (City of Portland and Multnomah County 2009). Another example is provided by the City of Paris (France), which included the aim of sourcing seasonal, organic and local produce to be served in schools and staff canteens across the city within its climate action plan (Mairie de Paris 2007).

Current food production and consumption systems are inherently unsustainable, not least because agriculture alone is responsible for approximately $30-35 \%$ of greenhouse gas emissions globally, mainly due to deforestation, direct emissions from fertilised soils, livestock rearing and rice cultivation (Foley et al. 2011). Additionally, food systems contribute to climate change also at post-farm stage, mainly as a consequence of the use of fossil fuels and refrigerant gases (Garnett 2011). Large volumes of water are necessary to produce food: it has been estimated that agriculture is responsible for around $70 \%$ of global freshwater withdrawals for irrigation and livestock production (Foley et al. 2011) and, if water absorbed in soil is included, the estimated contribution of food 
consumption to total water use is nearer $86 \%$ (Hoekstra and Chapagain 2006). Furthermore, research suggests that around one third of all food produced is not eaten, due to waste and losses at every step of the supply chain (FAO 2011). This implies that the resources and emissions embedded in those products have been used and released in vain; furthermore, food waste sent to landfill is a source of methane (25 times more polluting in terms of climate change than carbon dioxide (IPCC 2007)), further contributing to climate change. These pressures are expected to be exacerbated by a growing global population, a shift to "western diets" rich in meat and processed products and the effects of climate change on agricultural production. For these reasons, it is essential to determine which drivers are important in order to design more sustainable urban food systems.

This paper focuses on the potential offered by the public food sector (e.g. schools, hospitals, universities, care homes) in reducing the environmental impacts caused by food consumption at city level, both directly - by serving low-impact food - and indirectly - by setting a good example and therefore influencing the food choices of city dwellers (Morgan and Sonnino 2007; Sonnino and McWilliam 2011). The adoption of a robust methodology and a life cycle approach are fundamental to this aim, as this can ensure that the most effective reduction measures are applied and the right information on sustainable food choices is delivered, as opposed to the adoption of measures based on "common sense myths" on sustainable food (De Laurentiis et al. 2016).

In order to facilitate this type of initiative, we have developed a life cycle-based decision support tool for use by city councils and their contractors responsible for providing catering services to schools: the Environmental Assessment Tool for School meals (EATS). The purpose of EATS is to quantify the greenhouse gas emissions and water use of the meals served, in order to identify hotspot meals and ingredients and advise on reduction measures that can be implemented. The attention here is focused on the school catering sector, although with minimal adaptation the EATS tool could easily be applied to any public food sector, and indeed, the tool is equally applicable to all those engaged in designing menus, whatever the scale. This article presents the methodology followed in the creation of the tool and provides an example of its application through a case study in which the environmental impacts of 34 school meals are compared.

\section{Methods}

\subsection{Environmental assessment of catering services}

In the UK, the national guidelines for public procurement (DEFRA 2014) are mainly based on existing certification schemes (e.g. the FAO code of conduct for responsible fisheries (FAO 1995)) and on promoting resource-efficient practices of catering operations (such as the efficient use of water in catering services, the reduced consumption of bottled water, and the reduction of food and packaging waste). Notwithstanding the importance of such aspects, these guidelines lack a life cycle perspective, by focusing only on certain procurement decisions and certain stages of the supply chain which might not be the ones causing the highest impacts. For this reason, sustainability practices should always be supported by a specific evaluation of their environmental performance, such as reductions in greenhouse gas emissions or land use, to quantify the associated environmental savings (Cerutti et al. 2016). So far, only a handful of studies have explored the potential of adopting a life cycle approach to perform a quantitative environmental assessment of catering services.

A recent paper by Cerutti et al. (2018) focused on the analysis of several policy options adopted by the catering sector to reduce the greenhouse gas emissions of the service provided. These included applying changes to the menus, improving food storage and cooking practices and introducing programs for the recycling and composting of waste. Through the application of a life cycle approach, they estimated the greenhouse gases produced by the school catering service of the city of Turin in a baseline scenario and then quantified the savings obtained by applying each policy, in order to rank them in terms of their effectiveness. Amongst their findings, they found that the production of food was the stage responsible for most of the greenhouse gas emissions of the full service and that the policy promoting a change in the menus (by reducing the animal products served) was the most effective (leading to a $32 \%$ emissions reduction).

Benvenuti et al. (2016) used a life cycle assessment (LCA)based approach to assess menus served in public schools in Rome and to design optimised menus with low environmental impact (in terms of water consumption and greenhouse gas emissions) and that ensure the correct energy and nutrients intake. A similar approach was adopted by Ribal et al. (2016), who calculated the greenhouse gas emissions of a set of dishes served by a school caterer in Spain, basing their results on secondary data from LCA studies. Based on this, they developed an optimisation algorithm to generate menus that responded to a set of nutritional, environmental and economic requirements.

Another interesting application was developed by Saarinen et al. (2012), who used LCA to assess the impact on climate change and eutrophication potential of a set of meals served by a school in Finland, comparing them to equivalent meals served at home (either homemade or ready-to-eat). They found that school lunches resulted in the least impacts and that amongst those, the better performing were the vegetarian meals.

The work presented in this paper builds on the existing knowledge by applying a similar rationale to the school 
catering sector in the UK. The main element of novelty of this study is the development of a decision support tool that translates the scientific findings into practical measures and that can be directly used by city authorities and catering companies to assess the performance of the service provided and design low-impact menus.

\subsection{Description of the research method}

EATS is an Excel-based tool that enables its users (city councils, catering companies, etc.) to calculate the carbon footprint (CF) and water footprint (WF) of a portion of a school meal (metrics are discussed in the following section), based on its recipe.

As the purpose of EATS is to enable catering companies and local authorities to evaluate the environmental impact of most of the meals commonly served in UK schools, it was clear from the start that it could not be based on a detailed supply chain-specific LCA developed for each meal. This would have required significantly more time and resources than those available for this project. It was therefore decided to adopt a simplified approach in the calculation both of the CF and of the WF, based on existing secondary data available in the public domain. This would enable both the tool and the databases on which it is built to be freely distributed.

The functional unit used in this study is one portion of a school meal calculated from cradle to plate, and the system boundaries (shown in Fig. 1) include the following phases of the life cycle:

- Production

- Transport

- Meal preparation

As illustrated in Fig. 2 and Fig. 3, which show the user interface of EATS, the following inputs are required from the user.

- Name, weight and country of production of each ingredient

- Transport mode (for the ingredients produced outside the UK)

- Number of portions required

- Cooking appliances used and for how long

The respective outputs are given:

- Carbon footprint (CF)

- Water footprint (WF)

- Plots showing the contribution of each ingredient to the $\mathrm{CF}$ and the WF and the contribution of each phase of the life cycle to the $\mathrm{CF}$
To ensure that the tool can be used to assess the impact of most meals served in schools in the UK, an analysis of the Primary School Food Survey (in which school meals served for 2 weeks were collected across a nationally representative sample of 136 schools in England in 2009 (Haroun et al. 2009, 2011)) was performed and 104 ingredients were extracted and used as a starting point in the creation of the tool.

\subsubsection{Metrics used}

In this section, the metrics used to assess the environmental impact of a meal are outlined, and the methodology used to quantify the impacts is described.

Carbon footprint The carbon footprint of a product was defined in the international standard ISO 14067 (2013) as the sum of greenhouse gas emissions and removals in a product system, expressed as $\mathrm{CO}_{2}$ equivalent and based on life cycle assessment. This standard is based on the principles of the life cycle assessment (LCA) methodology provided in the ISO 14040 and ISO 14044. The $\mathrm{CO}_{2}$ equivalent of a specific amount of greenhouse gas is calculated as its mass multiplied by its global warming potential (GWP), a conversion factor that quantifies how much heat each greenhouse gas $\left(\mathrm{CO}_{2}\right.$, $\mathrm{N}_{2} \mathrm{O}, \mathrm{CH}_{4}$ ) traps in the atmosphere when compared to the amount of heat trapped by $\mathrm{CO}_{2}$ in a time horizon. The ISO 14067 refers to the IPCC (2007) for a list of GWP.

As explained in the introduction of this section, a simplified approach was adopted in this work to calculate the CF of a meal based on existing literature. This was calculated for three phases of its life cycle: production of the ingredients, transport to a generic school kitchen in the UK and meal preparation. The CF of the production phase of each ingredient was obtained by performing a meta-analysis of LCA literature. Emissions caused by transport of the ingredients and meal preparation were calculated separately from literature data. Emissions related to storage of food at regional distribution centres were not included as they are considered to be negligible (Brunel University 2008). Similarly, emissions related to refrigerated storage in school kitchens were not included as the purpose of the tool is to enable a comparison between different meals. [Any changes in the menus offered would be unlikely to affect the number and size of refrigerators utilised and their consequent energy use - at least in the short term (Garnett 2008)]. Emissions related to the end-of-life phase (e.g. waste management of plate leftovers) were not included as they were outside of the system boundaries of this study. The details of CF calculated within each phase previously defined are given below.

Phase 1-production Nearly 800 values of CF of the 104 ingredients recorded in the tool, calculated for the production phase, were collected from existing LCA studies for a variety 
Fig. 1 System boundaries and life cycle phases

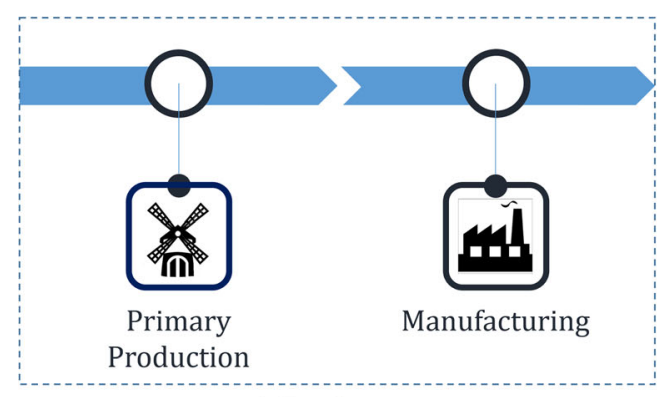

1- Production
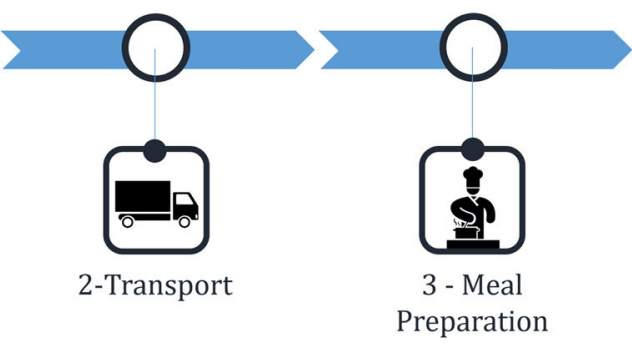

of countries of origin and production methods. Measures were taken to minimise the heterogeneity of the data collected (for instance it was made sure that the functional unit to which the $\mathrm{CF}$ was referred corresponded to $1 \mathrm{~kg}$ of edible product at farm gate in the case of unprocessed food items and $1 \mathrm{~kg}$ of edible product at factory gate in the case of processed items). More information is provided in the Electronic Supplementary Material, Section 1.

Then, for each food item, the average value of CF was calculated across the values collected, and therefore across different countries and production methods (with the exception of horticultural products in which case a distinction was made between those produced in heated greenhouses and those grown in unheated greenhouses or open fields; see the Electronic Supplementary Material for more information). This is the value used within the tool to calculate the CF relative to the production phase. A statistical analysis was performed to verify the meaningfulness of using average values of $\mathrm{CF}$; the results are provided in the Electronic Supplementary Material, Section 2.

Phase 2-transport For each ingredient, the tool calculates the emissions associated with their transport from the country of production to a generic school kitchen located in Birmingham, $\mathrm{UK}$, based on the information provided by the user. In order to quantify these emissions, a number of assumptions were made.

For food items produced in the UK, two different options are provided to users: a "UK generic" option, assuming road freight for a conservative distance of $250 \mathrm{~km}$, and a "UK less than 30 miles option", assuming road freight for a distance of $50 \mathrm{~km}$.

For all food items imported from outside the UK but inside the EU, the transport route was assumed to be from the capital city of the country of origin to Birmingham. Two alternative routes were considered; the first prioritised sea freight and the

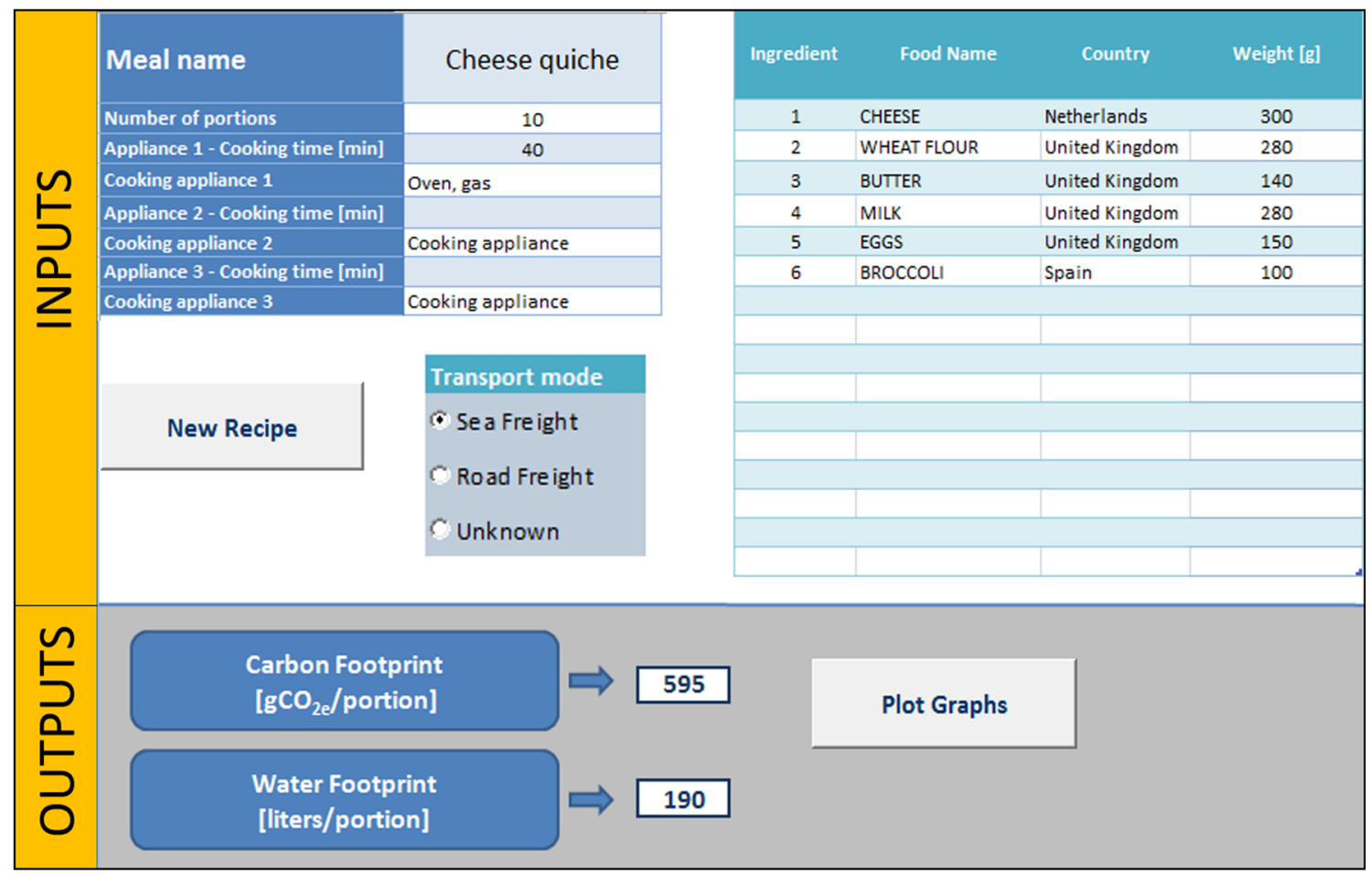

Fig. 2 Interface for the EATS tool—inputs and outputs part 1 


\section{Carbon Footprint of ingredients}

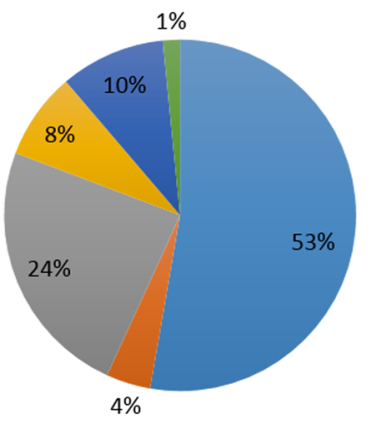

- CHEESE

- WHEAT FLOUR

BUTTER

MILK

EGGS

BROCCOLI

\section{Carbon Footprint of phases}

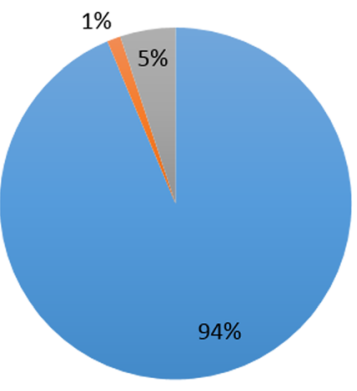

- Production

- Transport

w Preparation

\section{Water Footprint of ingredients}

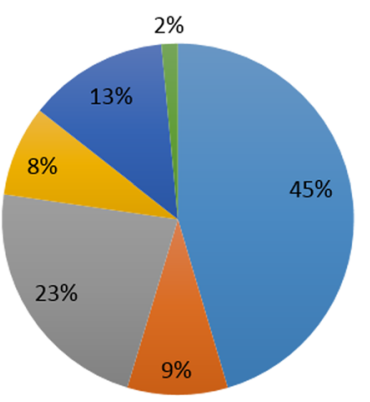

- CHEESE

WHEAT FLOUR

- BUTTER

MILK

EGGS

BROCCOLI

Fig. 3 Interface for the EATS tool—outputs part 2

second prioritised road freight. Rail freight was not considered as transport statistics show that in 2012 it accounted for less than $10 \%$ of the total inland freight transport of agricultural products in the EU (Directorate General for Internal Policies 2015).

Finally, for food items imported from outside the EU, a forfeit transport route was considered: this was calculated assuming that the food item would be shipped to the UK from Sydney. This last option (defined in the user interface as "World") applies also when the origin of the product is unknown. The reason for including this broad assumption is to ensure the user friendliness of the tool: as the user can choose the country of origin from a drop down menu, we decided that including all the existing countries would make the list too long, and therefore it would be better to include only EU countries and a "World" option for all the other cases.

Sea freight transport routes were taken from the website http://www.cargorouter.com/, sea distances were calculated from the website http://www.sea-distances.org/ and road distances were calculated from Google Maps. The transport vehicles considered were a refrigerated heavy good vehicle, with an average load, and an average-sized refrigerated cargo ship. The associated emissions were obtained from a dataset provided by DECC (Department of Energy \& Climate Change 2015). These include both the direct emissions deriving from the vehicle and the upstream emissions, referred to as Well-toTank.

Phase 3-meal preparation The preparation of a meal contributes to the overall CF due to the use of cooking appliances run on either electricity or natural gas. Average values of energy consumption for a range of cooking appliances were taken from the literature (Carlsson-Kanyama and Faist 2001). These values were converted into corresponding emissions $\left(\mathrm{gCO}_{2}\right)$ using coefficients for the UK electricity grid (1 $\left.\mathrm{kWh}=0.5311 \mathrm{KgCO}_{2}\right)$ and natural gas consumption $\left(1 \mathrm{kWh}=0.2093 \mathrm{KgCO}_{2}\right.$ ) provided by DEFRA (2015).

Water footprint A number of methods have been developed to quantify the WF of a product using different approaches (e.g. Hoekstra et al. 2009; ISO 2014). Within this study, the Water Footprint Network methodology was selected as the basis to calculate the WF. According to this method, the WF quantifies the water usage of a particular product, group of consumers or producers, and is defined as the total volume of freshwater used to produce goods and services (Hoekstra 2003). It is 
calculated as the total volume of direct and indirect water used, consumed and polluted. The three components of a $\mathrm{WF}$ are blue, green and grey water footprints, representing respectively the consumption of surface water and groundwater, the consumption of rain water stored in soil and the volume of water necessary to dilute the pollutants to water quality standards (Hoekstra et al. 2009).

The databases produced by Mekonnen and Hoekstra (2010a, b) provide the values of blue, green and grey water footprint at country level for crops, processed agricultural products and livestock products. No values are reported for wild fish products as WF analyses do not account for wild fish (Vanham et al. 2013). The aggregated value (sum of blue, green and grey component) of WF for each food item recorded in the tool (with the exception of fish items) was extracted from this source for each country of the EU28. Additionally, the global average value of WF was extracted. The WF of cultured fish species was extracted from Pahlow et al. (2015). The tool calculates the WF only for the production phase, as in the calculation of the WF according to the methodology by Hoekstra (2003), where blue, green and grey water are taken into account, the contribution of the other phases is negligible in comparison. This assumption is in line with similar research (Jefferies et al. 2012; Strasburg and Jahno 2015).

\subsubsection{Waste along the supply chain}

In this study, the environmental impact of a meal is calculated based on the CF and WF of each food item included in the ingredients list, according to the quantity of each ingredient as expressed by the recipe. However, when allocating to a meal the environmental impact it has caused during its life cycle, it is important to take into consideration losses and waste along the supply chain. Due to wastage levels at post-farm stages, a larger amount of each food item will have to be produced than the quantity expressed by the recipe, as illustrated in Fig. 4 with an example.

In the case illustrated, the recipe considers $100 \mathrm{~g}$ of broccoli; this means that a larger amount ( $108 \mathrm{~g}$ ) will need to enter the school kitchen, due to waste at preparation stage (quantified considering only unavoidable and possibly avoidable waste) (Quested et al. 2012). Furthermore, as a consequence of losses during distribution, an even larger quantity will have to leave the packaging facility (119 g). When adding considerations on losses during processing and packaging and at post-harvest handling stage (which include quality checks and damage to crops during grading and sorting), the amount of broccoli that needs to be harvested is $127 \mathrm{~g}$. Considerations on losses during the agricultural production were not included, due to the assumption that wastage happening at this stage had already been taken into account in the literature sources consulted to extract the environmental impacts relative to the production phase. Levels of wastage at each phase of the life cycle were collected from the literature for seven groups of food items (i.e. cereals, roots and tubers, oilseeds and pulses, fruits and vegetables, meat, fish and dairy) (FAO 2011; Quested et al. 2012).

\subsubsection{Case study}

An example of an application of the tool is provided in this section. Thirty-four recipes of best practice meals, taken from the online Recipe Hub (The School Food Plan 2015), were analysed using EATS. All of them comply with the nutritional requirements of the British government (Department for Education 2015).

As the recipes used for the development of the case study provided only part of the information required for the calculation of the environmental impacts as specified in Sect. 2.2 (the ingredients used and the cooking procedure, but not the country of origin of the ingredients, their seasonality or their transport mode), a number of assumptions were made. Specifically, the following was assumed:

1. All the recipes were made of seasonal ingredients (therefore, the use of heated greenhouses is not required for the production of horticultural products).

2. For all food items that are commonly produced in the UK (even if only during part of the year), this was assumed to be the chosen point of origin (see below).

3. In all the other cases (e.g. fruits that cannot grow in the UK in any season), the country of origin was chosen as the country that is the first supplier of that food item to the UK (see below).

4. The transport mode was assumed to be via truck and road for food items produced in the UK, and cargo ship for food items imported from overseas (i.e. the "prioritised sea freight" option described in Sect. 2.2.1 - phase 2).

5. The cooking appliances used were assumed to be gas oven and gas hob (AEA 2012).

In order to verify whether a food item can be produced in the UK (assumption 2), the amounts of each food item produced in the UK in 2013 were taken from the FAOSTAT database (FAO 2013). For those food items that could not be found in this database, other sources were consulted (e.g. Ellis et al. (2015) was consulted to verify weather salmon is currently produced in the UK as the FAOSTAT database does not provide information on aquaculture). To identify the main supplier of the food items that were assumed to be imported from abroad (assumption 3), the overseas trade statistics for the UK were consulted (HMRC 2013).

The following section provides the results the case study analysis. Section 4.1.1 critically discusses the influence of the aforementioned assumptions on the results. This also provides 


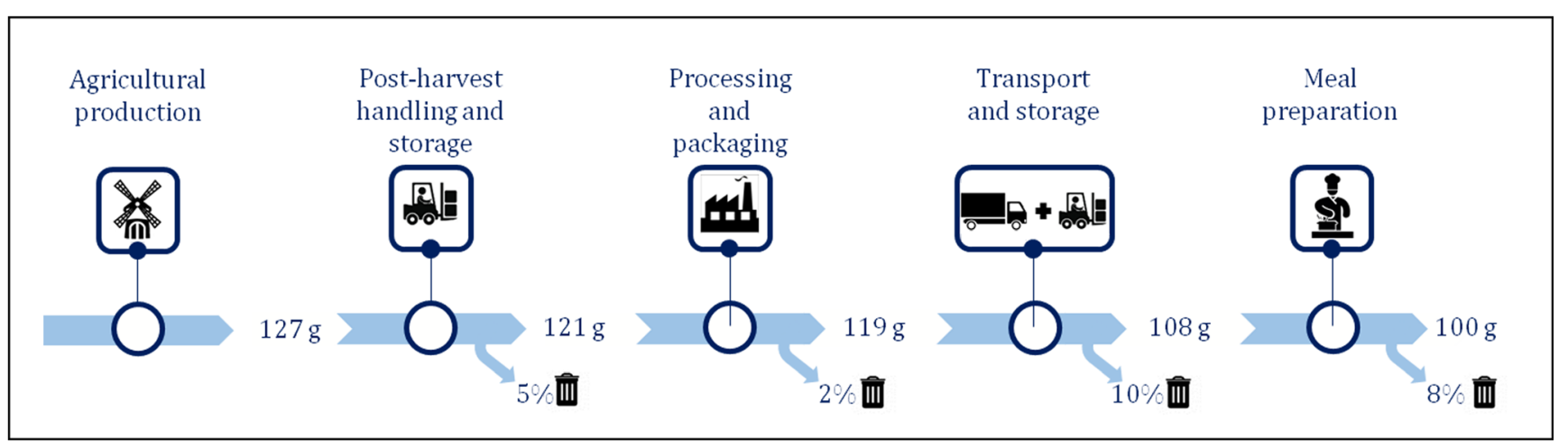

Fig. 4 Food and wastage flows through the life cycle of fruit and vegetable items

an opportunity to discuss the relative weight of procurement choices (such as the origin and seasonality of the ingredients) on the overall environmental impacts of the service provided.

\section{Results}

This section presents the results of the case study analysis, in which 34 different recipes of school meals are compared in terms of their CF and WF. The recipes analysed are differentiated according to whether they contain meat (M1-M13) or fish (F1-F9) or are vegetarian (V1-V12). The overall numerical results of $\mathrm{CF}$ and $\mathrm{WF}$ for all 34 recipes are presented in Table 1 and Figs. 5 and 6. For a breakdown of the ingredients used in each dish, see The School Food Plan (2015).

Figure 5 illustrates that there is a substantial difference between the CF of meals containing beef or lamb and all the other meals. Chicken-based, fish-based and vegetarian meals have comparable values of $\mathrm{CF}$, which vary according to the composition of the recipe (for instance recipes containing dairy ingredients and rice have generally higher impacts than those containing pulses and other types of starches). This is in line with similar research (Chen et al. 2016) showing how a comparison between meals based on existing recipes provides more insights, and can sometimes lead to unexpected results, than a comparison across different food items on a per kilogramme basis. For instance the vegetarian lasagne, V4 (552 $\mathrm{g} \mathrm{CO}_{2 \mathrm{e}}$ ), has a $49 \%$ higher $\mathrm{CF}$ than the chicken couscous, M5 (370 $\mathrm{g} \mathrm{CO}_{2 \mathrm{e}}$ ). In terms of WF, fish-based, chicken-based and vegetarian recipes tend to present lower impacts, whilst pork-, beef- and lamb-based recipes present the highest impacts. One of the fish-based recipes (F1) presents the lowest value of WF (equal to $16 \mathrm{~L}$ ) compared to the other meals analysed. This is because it is made with wild caught fish (which in the tool has WF equal to zero), whilst all the other fish-based recipes are made with farmed fish. As in the case of $\mathrm{CF}$, the values of WF of some vegetarian recipes are sometimes higher than meat-based recipes, especially when they are rich in dairy ingredients or rice.
For each recipe analysed, EATS provides the user with the contribution of each phase of the life cycle to the CF (Fig. 3). The average values of the contribution of each phase calculated across the three groups of recipes analysed are presented in Fig. 7. It is possible to see how the production phase is predominant in all cases, followed by the preparation phase and the transport phase (this is in line with existing literature, e.g. Davis et al. 2010; Saarinen et al. 2012; Sonesson et al. 2005; Virtanen et al. 2011). The small influence of the transport phase is partly influenced by the assumptions made on the origin of the ingredients. As the production phase is predominant in both CF and WF, the choice of the composition of the meals is crucial to the designing of low-impact menus.

\section{Discussion}

The case study presented shows how the composition of a meal significantly influences its environmental impact (both in terms of greenhouse gas emissions and of water use), and therefore highlights the potential savings achievable by applying changes to the menus. This is in line with previous research that identified menu changes as the most effective measure to improve the environmental performance of the catering sector (Cerutti et al. 2018; Jungbluth et al. 2016). However, the cultural acceptability of applying changes to school menus needs to be further investigated. A study by O'Keefe et al. (2016) identified a number of barriers to changing eating practices (including the resistance to any perceived choice restriction, and the perception that meat plays an important role in providing a nutritionally complete diet, especially for children). This suggests that less radical changes (e.g. if meat was partially replaced by an alternative source of protein 3 days a week rather than if no meat option was available for 1 day a week) would be more easily accepted by parents and pupils and would not be seen as a constraint to their freedom of choice.

The large predominance of the production phase on the $\mathrm{CF}$ of a meal found in this study (Fig. 7) is partly a consequence of the choice of system boundaries. The decision to define them as 
Table $1 \mathrm{CF}$ and WF of the 34 meals analysed (all values refer to one portion)

\begin{tabular}{|c|c|c|c|}
\hline Meal code & Name & $\mathrm{CF}\left(\mathrm{g} \mathrm{CO}_{2 \mathrm{e}}\right)$ & WF (L) \\
\hline M1 & Beef Bourguignon & 2215 & 634 \\
\hline M2 & Beef chow mein & 1618 & 513 \\
\hline M3 & Beef meatballs & 1867 & 518 \\
\hline M4 & Chicken curry & 696 & 486 \\
\hline M5 & Chicken couscous & 371 & 286 \\
\hline M6 & Chicken balti pie & 440 & 325 \\
\hline M7 & Chicken chasseur & 455 & 283 \\
\hline M8 & Chicken fajitas & 490 & 248 \\
\hline M9 & Chicken with rice & 452 & 337 \\
\hline M10 & Roast chicken & 628 & 447 \\
\hline M11 & Lamb shepherd's pie & 2064 & 531 \\
\hline M12 & Pork meatballs & 716 & 362 \\
\hline M13 & Macaroni and cheese with pork & 803 & 534 \\
\hline F1 & Pollok fillet & 145 & 16 \\
\hline $\mathrm{F} 2$ & Salmon and broccoli pasta & 376 & 255 \\
\hline F3 & Salmon fishcake & 377 & 207 \\
\hline F4 & Salmon and vegetable noodles & 385 & 264 \\
\hline F5 & Salmon fish pie & 441 & 250 \\
\hline F6 & Salmon pasta & 400 & 265 \\
\hline F7 & Salmon pie & 432 & 247 \\
\hline F8 & Spaghetti marinara & 520 & 262 \\
\hline F9 & Tandoori salmon & 309 & 186 \\
\hline V1 & Beetroot patties & 266 & 147 \\
\hline V2 & Cheese quiche & 421 & 162 \\
\hline V3 & Vegetarian pie & 470 & 269 \\
\hline V4 & Vegetable lasagne & 554 & 399 \\
\hline V5 & Chilli with rice and beans & 455 & 344 \\
\hline V6 & Pizza with lentil sauce & 381 & 148 \\
\hline V7 & Cheese quesadilla & 349 & 183 \\
\hline V8 & Pizza & 396 & 134 \\
\hline V9 & Lentil and bean patties & 136 & 208 \\
\hline V10 & Tortilla & 434 & 152 \\
\hline V11 & Vegetarian burrito & 357 & 305 \\
\hline V12 & Vegetable curry & 550 & 311 \\
\hline
\end{tabular}

from cradle to plate reflects the purpose of EATS. As this tool is aimed at enabling a comparison across different menu choices, the final stage of the life cycle of a meal (i.e. waste management of plate leftovers) was not included in the analysis, as it was expected that a similar amount of plate leftovers would be generated across all meals. If this stage of the life cycle had instead been included in the system boundaries, by assuming for instance a fixed ratio of plate leftovers, this would have affected the final results in different ways depending on the waste treatment technology chosen. For instance, some waste treatment methods enable credits to be obtained (e.g. by using a waste incineration facility to generate electricity), as opposed to landfilling, which by causing methane emissions would increase the CF of the system (Silvenius et al. 2014).
In the following sections, the influence of a number of assumptions on the results is tested through two sensitivity analyses and the strengths and limitations of the EATS tool are critically discussed.

\subsection{Sensitivity analysis of the results}

Two separate sensitivity analyses were performed. The first aimed at assessing the influence of the assumptions made on the origin of the ingredients, their seasonality, the transport mode and the type of cooking appliances used on the results provided by the EATS tool. The second aimed at assessing the influence of the choice of the functional unit on the results. 


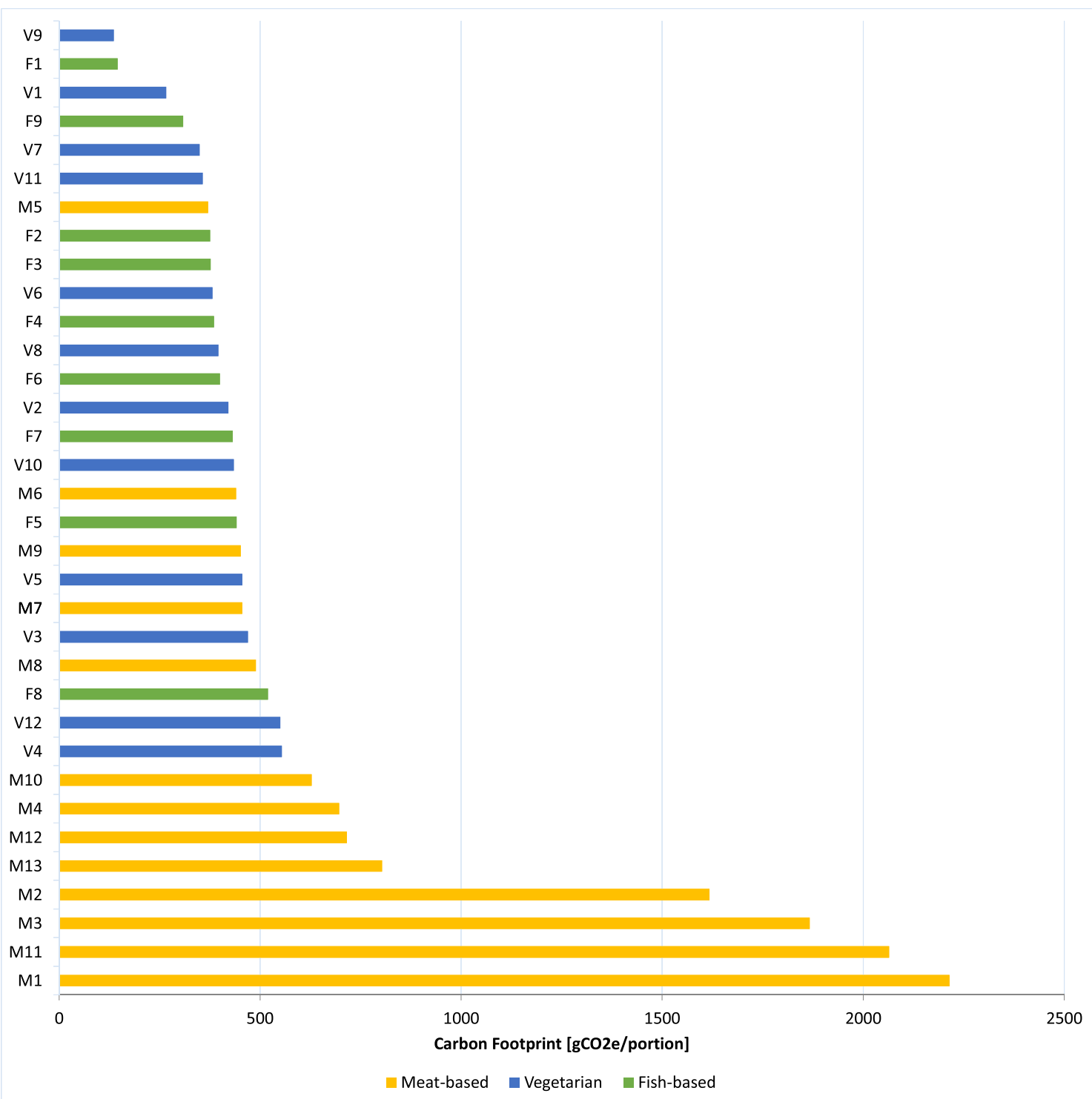

Fig. $5 \mathrm{CF}$ of the 34 meals analysed

\subsubsection{First sensitivity analysis}

Meal M8 was selected from the previous dishes analysed in the case study (as it has mid-range values of both CF and WF), and six alternative scenarios were created by varying each time one of the assumptions of the baseline case (presented in Sect. 2.2.3).

Table 2 shows the alternative scenarios developed and the parameters modified in each case.

In scenario M8.1, it is assumed that the origin of all ingredients is unknown, and therefore the option "World" is selected for each ingredient. In scenario M8.2, the origin of the ingredients is the one assumed in the baseline scenario but the transport mode is assumed to be by truck for all the ingredients sourced from within the EU. In scenario M8.3, the ingredients sourced from the UK are assumed to have travelled $50 \mathrm{~km}$ to reach the school kitchen (as opposed to $250 \mathrm{~km}$ of the baseline case). In scenarios M8.4 and M8.5, it is assumed that the horticultural products used in the recipe are not seasonal; in the first case, they are still produced in the UK, and therefore they have been produced in heated greenhouses, whilst in the second, it is assumed that these ingredients are sourced from Spain. In scenario M8.6, the energy source in the school kitchen is changed from natural gas to electricity.

The results of the sensitivity analysis are shown in Table 3 and Fig. 8. When the origin of all the ingredients is unknown (scenario M8.1) and therefore a conservatively long forfeit transport distance is assumed in the calculations (as explained in Sect. 2.2.1), the CF is $18 \%$ higher compared to the baseline case. Conversely, applying the hypothesis of locality to all the ingredients produced in the UK (scenario M8.3) leads to a minor reduction in the $\mathrm{CF}(-1 \%)$ compared to the baseline. 


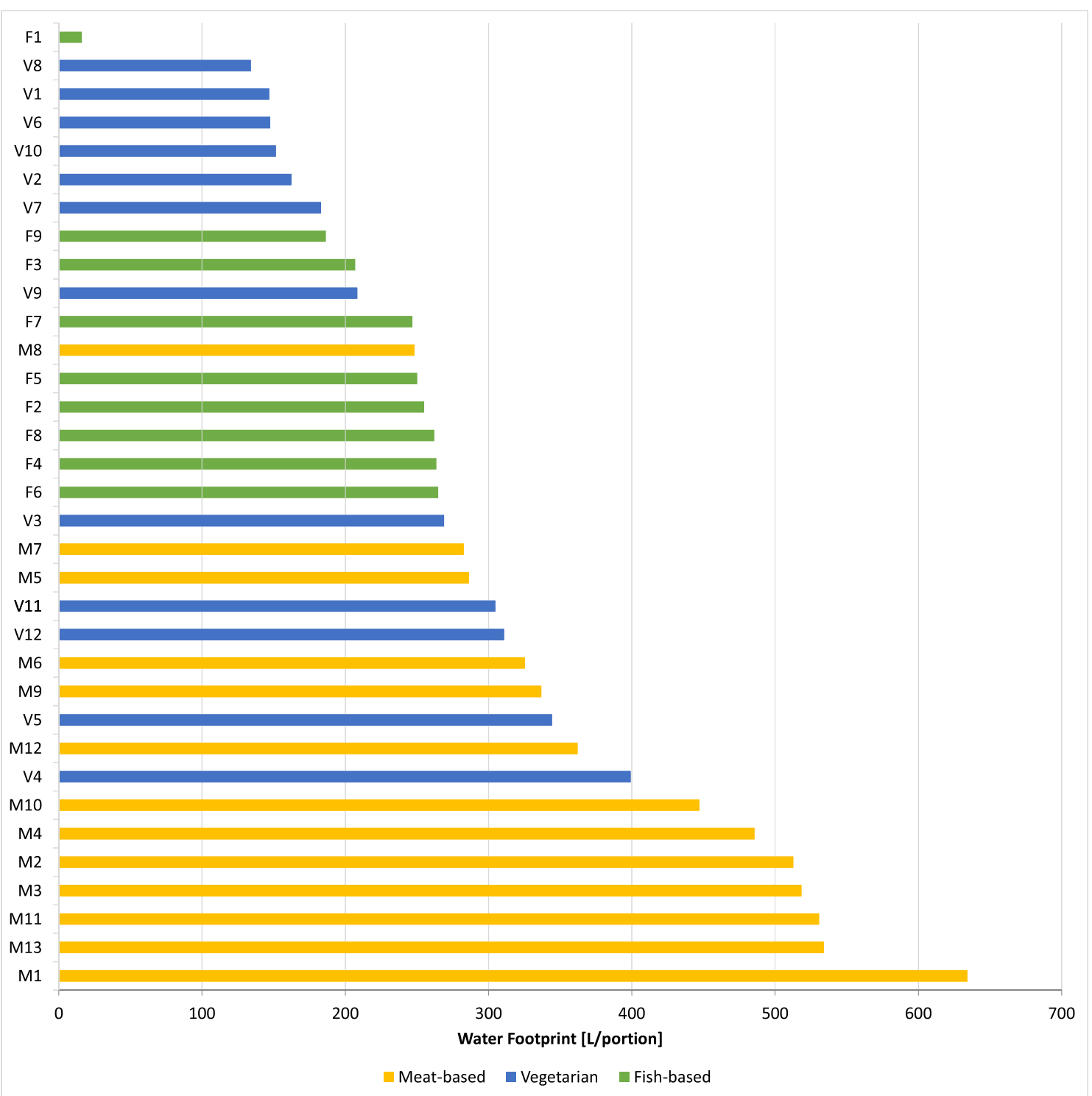

Fig. $6 \mathrm{WF}$ of the 34 meals analysed

Fig. 7 Average contribution of each phase to the CF of fishbased, meat-based and vegetarian meals

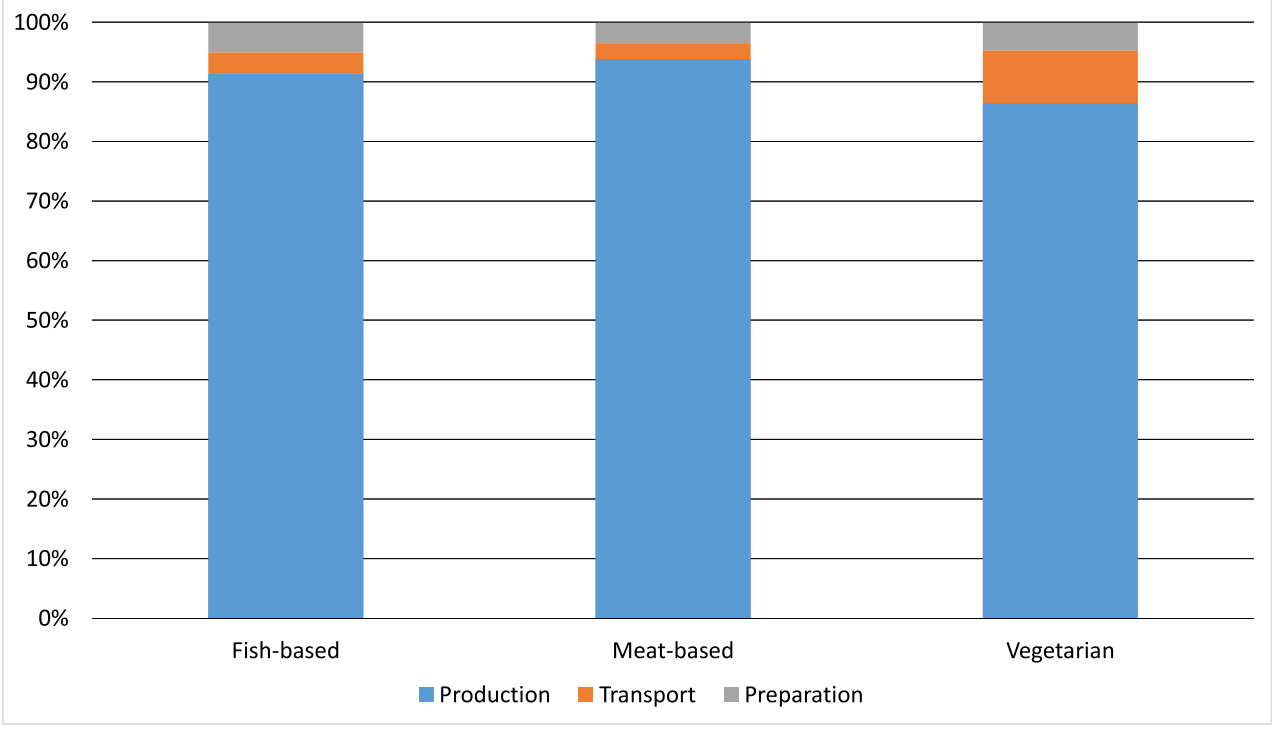


Table 2 Baseline and alternative scenarios for sensitivity analysis

\begin{tabular}{|c|c|c|c|c|}
\hline Scenario & Origin of ingredients & Horticultural production & Transport mode & Cooking appliances \\
\hline M8 (baseline) & $\begin{array}{l}\text { UK seasonal products whenever } \\
\text { possible (see Sect. } 2.2 .3 \text { ) }\end{array}$ & $\begin{array}{l}\text { Open field/non-heated } \\
\text { greenhouse }\end{array}$ & $\begin{array}{l}\text { Truck (UK products) and } \\
\text { cargo ship otherwise }\end{array}$ & Gas hob \\
\hline M8.1 & Unknown ("World") & Baseline & Baseline & Baseline \\
\hline M8.2 & Baseline & Baseline & $\begin{array}{l}\text { Truck (EU products) and } \\
\text { cargo ship otherwise }\end{array}$ & Baseline \\
\hline M8.3 & $\begin{array}{l}50 \mathrm{~km} \text { away for UK products, } \\
\text { baseline for remaining products }\end{array}$ & Baseline & Baseline & Baseline \\
\hline M8.4 & Baseline & Heated greenhouse & Baseline & Baseline \\
\hline M8.5 & $\begin{array}{l}\text { Horticultural products from Spain, } \\
\text { baseline for remaining products }\end{array}$ & Baseline & Baseline & Baseline \\
\hline M8.6 & Baseline & Baseline & Baseline & Electric hob \\
\hline
\end{tabular}

Changes in the transport mode of the products sourced from outside the UK and within the EU (replacing transport via cargo ship with refrigerated trucks) lead to an increase in the CF by $3 \%$ (scenario M8.2). When the horticultural products in a recipe are out of season in the UK, there are two alternative options: they can be produced in the UK in heated greenhouses (scenario M8.4) or imported from overseas (scenario M8.5). The first scenario presents the highest value of $\mathrm{CF}$ (46\% increase compared to the baseline), whilst the second present a negligible increase (smaller than 1\%). This result clearly shows that when choosing local products that are not seasonal, the reduction in the CF due to shorter transport distances is most likely outweighed by the significant increase in the $\mathrm{CF}$ of production, deriving from the use of heated greenhouses. The last scenario (M8.6) investigates the influence of preparing a meal with cooking appliances running on electricity rather than on natural gas; in this case, the increase in the total $\mathrm{CF}(+5 \%)$ is related to the current UK average electricity production mix (therefore, if the electricity was instead produced through renewable energy sources, this scenario would most likely present a lower CF compared to the baseline).

The sensitivity analysis shows that variations in the assumptions made on cooking appliances, transport distances for the ingredients produced in the UK and transport mode are not likely to significantly affect the results (all variations of the results are equal or smaller than $5 \%$ ). The parameters that can affect the results are the production method of horticultural products and the choice of the country of origin of the ingredients. This analysis shows how the concepts of locality and seasonality cannot be separated and that "local food" does not always mean "sustainable food".

When the same analysis was applied to the WF, out of the six alternative scenarios presented above, only scenarios M8.1 and M8.5 presented different results. This is because the calculation of the WF performed by the tool is influenced neither by the production method nor by any assumptions relating to the transport or preparation phase (as it is only calculated for the production phase). However, unlike the calculation of the $\mathrm{CF}$ of the production phase, the calculation of the WF of production is affected by the origin of the ingredients. Hence, in scenario M8.1, which assumes an unknown origin for all the ingredients, the WF is calculated using the average global value of WF of each ingredient. This causes an increase in the WF of the meal analysed from $248 \mathrm{~L}$ per portion (baseline case) to $545 \mathrm{~L}$ per portion (scenario M8.1). In scenario M8.5, where the horticultural ingredients are assumed to be produced in Spain rather than in the UK, the WF is slightly higher (250 L per portion). The significantly higher value of scenario M8.1 is a consequence of the fact that, for food items that can be produced in the UK, often the WF associated with the production in the UK is smaller than the global average value of WF (Mekonnen and Hoekstra 2010a, b). It is therefore possible to state that the only assumption that can significantly influence the final result in the calculation of the WF of
Table 3 Results of sensitivity analysis on $\mathrm{CF}$ ( $\mathrm{g} \mathrm{CO}_{2 \mathrm{e}}$ /portion)

\begin{tabular}{lllcll}
\hline Scenario & CF (tot) & CF (production) & CF (transport) & CF (preparation) & Variation from baseline \\
\hline M8 & 490 & 455 & 20 & 15 & - \\
M8.1 & 579 & 455 & 109 & 15 & $+18.2 \%$ \\
M8.2 & 507 & 455 & 37 & 15 & $+3.5 \%$ \\
M8.3 & 483 & 455 & 13 & 15 & $-1.4 \%$ \\
M8.4 & 714 & 680 & 20 & 15 & $+45.7 \%$ \\
M8.5 & 492 & 455 & 23 & 15 & $+0.4 \%$ \\
M8.6 & 514 & 455 & 20 & 39 & $+4.9 \%$ \\
\hline
\end{tabular}


Fig. 8 Results of sensitivity analysis on the CF of meal M8

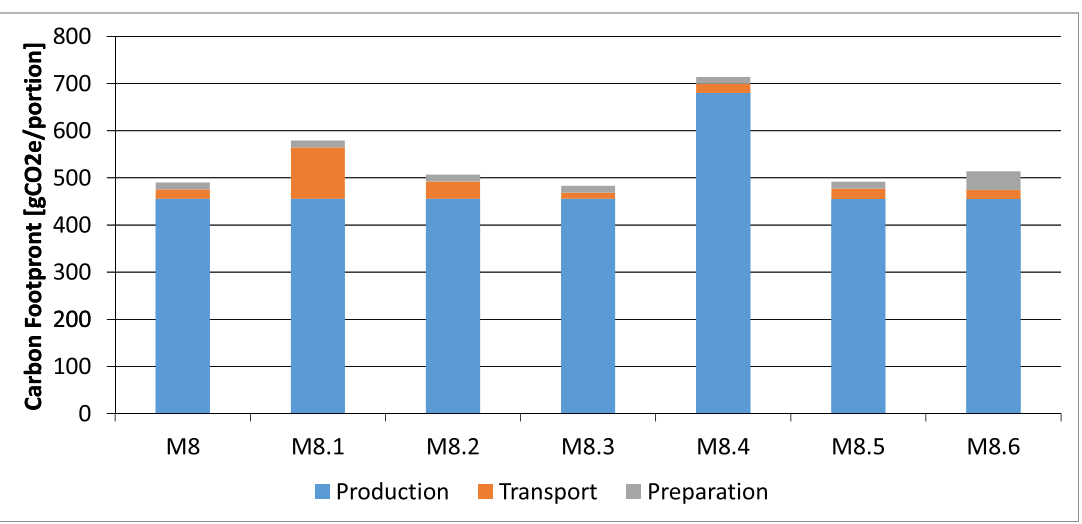

a recipe is the origin of the ingredients, and that when this information is not available the results will most likely be overestimated.

\subsubsection{Second sensitivity analysis}

The functional unit used by the EATS tool is one portion of each meal. However, this entails that meals that have different nutritional properties are directly compared, which could lead to biased results. In order to study how this methodological choice affects the results, a sensitivity analysis was performed comparing the results obtained above with two alternative sets of results, calculated using different functional units. These were respectively $100 \mathrm{kcal}$ and $1 \mathrm{~g}$ of proteins. The energy and protein content of each meal were calculated based on the recipe and the energy/protein content of the ingredients, as provided by Public Health England (2015).

Figure 9 shows the resulting values of CF and WF calculated with the three chosen functional units, for 10 selected meals (for the full set of meals, please refer to the Electronic Supplementary Material, Section 3). It is possible to see that the beef-based meals (M1 and M11) present the highest CF regardless of the choice of the FU (in the case of WF, this is only true for meal M1). However, the choice of the functional unit has a rather large impact on the results, as found by previous research (Kendall and Brodt 2016). This is particularly true for the vegetarian meals, which are disadvantaged by the fact of having low energy and protein content, and therefore present similar or higher impacts than the chicken-based meal (M4) when using the two alternative functional units. Fishbased meals (F1, F5 and F8) are less affected by the choice of the functional unit, and are towards the lower end in each case.

It is important to highlight that the energy content and the protein content of a meal do not provide a complete picture of its nutritional value. For this reason, more sophisticated functional units have been defined to better capture the nutritional properties of different types of food when comparing their environmental impact (e.g. van Dooren 2016). Nevertheless, as the purpose of the tool here presented was to provide results that can be easily understood by a non-scientific audience, using a portion-based functional unit was considered to be the best option.

\subsection{Strengths and limitations}

The EATS tool was developed in order to provide local authorities and catering companies with a user-friendly tool that would enable them to easily compare alternative recipes in order to design school menus considering, alongside nutritional considerations, also their environmental performance.

By providing users with a breakdown of the contribution of each ingredient to the total $\mathrm{CF}$ and WF of a recipe, and of each phase of the life cycle to the total CF (Fig. 3), the EATS tool enables them to immediately identify where the highest impact(s) lie across the life cycle, and which ingredient(s) are responsible for most of the impacts. In this way, it enables identification of the most effective reduction measures (e.g. by replacing hotspot ingredients in a recipe with low-impact alternatives, sourcing some ingredients from a different country, introducing meatless days in the menu). Notwithstanding this potential, one should keep in mind that the fundamental importance of school meals is to provide healthy and nourishing food to students. Therefore, the EATS tool could be used either to compare existing recipes deemed to be equal in terms of nutritional value or to suggest alternative recipes after testing their nutritional quality.

Furthermore, the EATS tool can help to dismantle some "common sense myths" on sustainable food (De Laurentiis et al. 2016), such as the general perception that food sourced locally is always associated with a lower environmental impact (as shown in the previous section, in the two cases where some of the ingredients were not seasonal, importing them from Spain - scenario M8.5-rather than sourcing them from the UK, where they are produced in heated greenhousesscenario M8.4 - leads to a significantly lower CF).

The authors are aware that a restriction of the impact categories reduces the breadth of the study, and in our study only two indicators of the environmental impacts were considered 

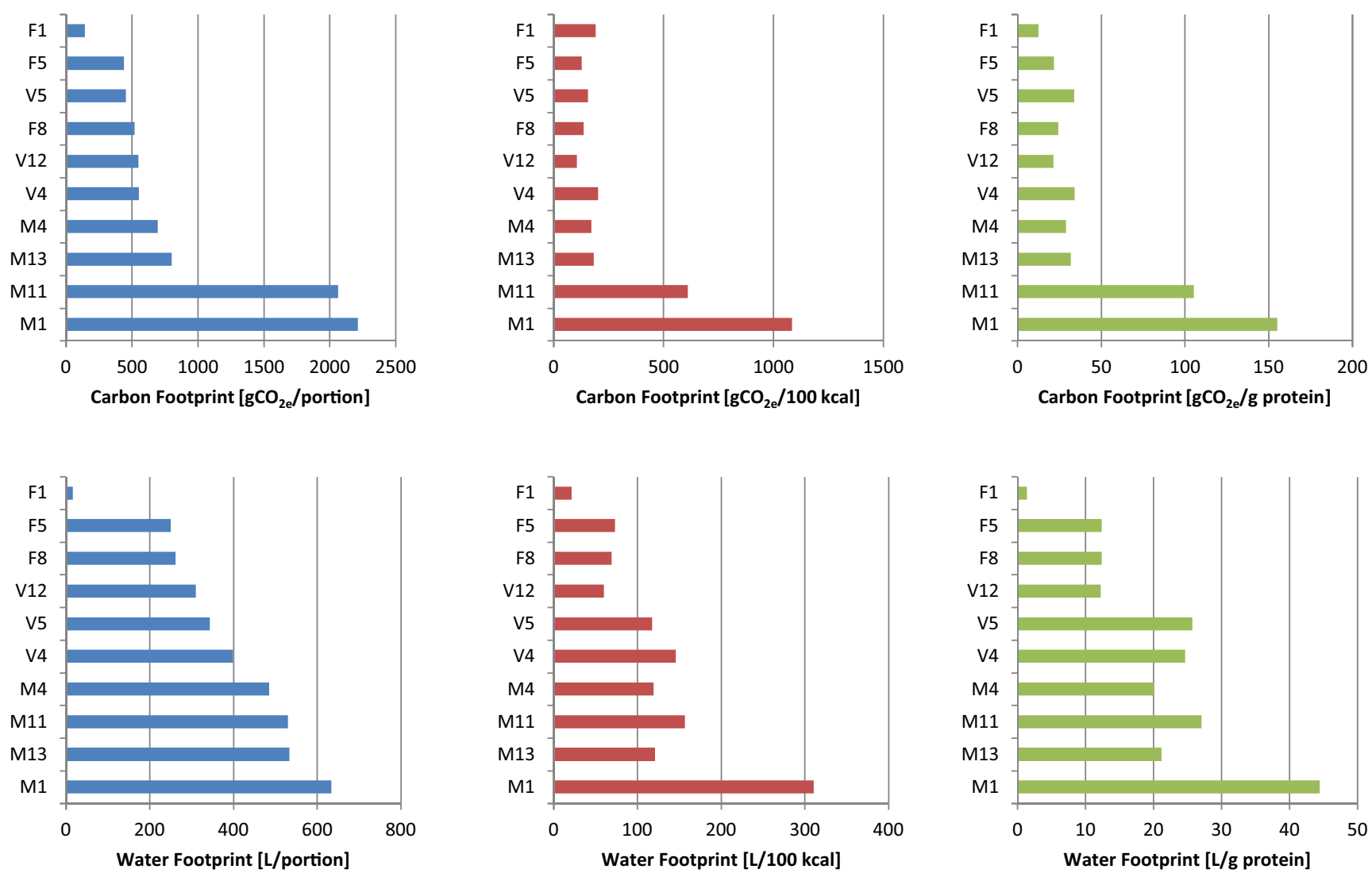

Fig. $9 \mathrm{CF}$ and WF of ten selected meals calculated with different functional units: one portion, $100 \mathrm{kcal}, 1 \mathrm{~g}$ of protein

(i.e. $\mathrm{CF}$ and $\mathrm{WF}$ ). This was mainly due to data availability and the requirement of providing results that are easily communicable to an audience of non-LCA experts (e.g. city councils and catering companies). Furthermore, the choice of presenting the WF in its aggregated form (as the sum of the blue, green and grey components) might be considered misleading, due to the fact that significantly different opportunity costs exist between blue and green water, and due to the different physical meaning of grey water when compared to blue and green water (Hess et al. 2015; Ridoutt and Pfister 2010). However, this choice was made in order to provide a clear and accessible set of results.

Some scholars have argued that a weakness of the WF metric is the fact that it is limited to the representation of the quantity of water used, without estimating the related environmental impacts (Jeswani and Azapagic 2011). In other words, it fails to stress the consumption of virtual water sourced from regions that may be more water scarce due to climatic conditions (Chen et al. 2016; Ridoutt et al. 2009). Consequently, a number of alternative methods have been proposed to account for the environmental impact related to water use (e.g. Frischknecht et al. 2009; Milà i Canals et al. 2009; Pfister et al. 2009), in order to align the concept of WF to the one of the impact categories within LCA. Amongst these, the method suggested by Pfister and colleagues enables the assessment of a "water scarcity weighed WF" based on two main factors: the blue water consumption and the regional "water stress index" (WSI) which is used as a characterisation factor to assess water deprivation. The WSI is available at any spatial scale; however, it is recommended by the authors to assess the impacts related to water use at a watershed level, as the national level data would not be truly representative of the actual impact (Jeswani and Azapagic 2011; Pfister et al. 2009). This method was partially adopted in the ISO's LCAbased WF standard (ISO 2014) which recommends taking into account local differences in water scarcity when assessing the water scarcity footprint. However, as the purpose of the EATS tool was to enable the calculation of the WF of a recipe, based on the (often scarce) information available to catering companies and local authorities, it was deemed not feasible to include this level of detail in the analysis. That is not to say that any future development of the tool could not integrate such modifications.

The background studies used to collect values of CF assessed the impacts of food products produced in different countries and with different production methods (with exception of horticultural products; for more information, see the Electronic Supplementary Material). Furthermore, even though the LCA methodology is ISO standardised (ISO 2006a, b), a number of methodological choices are left to the practitioner (e.g. system boundaries definition, choice of functional unit). Whilst measures were taken when collecting 
the data to limit the consequent variation in the results, (as explained in Section 1 of the Electronic Supplementary Material), sometimes there is a lack of information disclosed within literature sources making vetting virtually impossible. Even though these methodological differences can be considered small (Clune et al. 2017; Teixeira 2015), a wider consensus on best practice methods for food LCA would enable more accurate results in future analysis.

\section{Conclusions}

Food consumption is often overlooked when assessing the environmental sustainability of cities. This is a consequence of food being perceived as a predominantly rural issue (Pothukuchi and Kaufman 1999) and of the widespread adoption of territorial-based approaches when assessing the carbon emissions and resource use of a city. However, a number of studies have shown how, when this element is taken into account, its contribution is surprisingly, and to many remarkably, influential, with emissions being approximately comparable to those arising from household energy use and private transport. This article argues that an increased awareness and a better understanding of the implications of food choices made by city dwellers would prompt city authorities, who are almost universally seeking to reduce carbon emissions and other planetary impacts, to implement specific measures aiming at reducing the environmental impact of urban food consumption.

The research reported herein has resulted in EATS, a life cycle-based tool that provides the evidence base to support decision-makers responsible for providing school meals in the delivery of an environmentally sustainable service. The EATS tool enables its users to carry out a cradle-to-plate assessment of the carbon footprint and water footprint of a recipe with the purpose of identifying hotspots and suggesting better performing menus. The paper demonstrates the efficacy of the tool by its application to 34 meals. It compares them in terms of their carbon footprint and water footprint, showing substantial variations amongst them and a general trend of lower impacts in the case of meat-free meals. Additionally, it showed how procurement choices (e.g. seasonality of the ingredients, country of origin, transport mode) affect in different ways the final impacts of a meal. These results prove that diligence in the choice of the type of meals served by a caterer can have a very significant impact on the overall environmental performance of the service provided - simple changes that, when multiplied up and extended to food consumption in cities more generally, can have a profound influence on the planetary impacts of city living. Given that cities are striving so hard to make incremental changes elsewhere in city living (such as in the energy and transport spheres), adopting the principles generated by this research could have a major impact on the sustainability and resilience of cities.

Nevertheless, the analysis presented here only focuses on the environmental impact of school meals. It is important to recognise that the main drivers in the design of school menus are nutritional considerations and costs (Ribal et al. 2016). To achieve a holistic assessment, additional considerations need to be made to enable an evaluation of the synergies and tradeoffs between the provision of economically sustainable, healthy and low-impact meals. This would represent a valuable future addition to the tool, and manifestly contribute to the health and well-being of people in cities, considerations that lie at the heart of the Liveable Cities Programme.

Moreover, although this paper has highlighted the importance of adopting a life cycle approach to understand the impacts related to urban food consumption, the research has the potential to be expanded further to incorporate other resource flows (including waste) and their interactions, at different spatial scales - a catalyst for fundamental change to a city's urban metabolism. In the future, therefore, it is anticipated that this will contribute to more sustainable, resource-secure (hence resilient), thriving and liveable cities across the world.

Acknowledgements The authors with to thank the Engineering and Physical Sciences Research Council for their support under the Liveable Cities Programme Grant (EP/J017698). We thank the two anonymous reviewers for their constructive criticism and suggested improvements.

Open Access This article is distributed under the terms of the Creative Commons Attribution 4.0 International License (http:// creativecommons.org/licenses/by/4.0/), which permits unrestricted use, distribution, and reproduction in any medium, provided you give appropriate credit to the original author(s) and the source, provide a link to the Creative Commons license, and indicate if changes were made.

\section{References}

AEA (2012) Sector guide, industrial energy efficiency accelerator, contract catering sector

Benvenuti L, De Santis A, Santesarti F, Tocca L (2016) An optimal plan for food consumption with minimal environmental impact: the case of school lunch menus. J Clean Prod 129: 704-713

Blanco G et al (2014) Drivers, trends and mitigation. Cambridge University Press, Cambridge and New York

Brunel University (2008) Greenhouse gas impacts of food retailing. Report F0405 for Defra. London

Carlsson-Kanyama A, Faist M (2001) Energy use in the food sector: a data survey. FMS Report

Cerutti AK, Contu S, Ardente F, Donno D, Beccaro GL (2016) Carbon footprint in green public procurement: policy evaluation from a case study in the food sector. Food Policy 58:82-93

Cerutti AK, Ardente F, Contu S, Donno D, Beccaro GL (2018) Modelling, assessing, and ranking public procurement options for 
a climate-friendly catering service. Int J Life Cycle Assess 23:95115

Chen DM, Tucker B, Badami MG, Ramankutty N, Rhemtulla JM (2016) A multi-dimensional metric for facilitating sustainable food choices in campus cafeterias. J Clean Prod 135:1351-1362

City of Portland \& Multnomah County (2009) Climate action plan http:// www.portlandoregon.gov/bps/49989. Accessed 30 March 2017

Clune SJ, Crossin E, Verghese K (2017) Systematic review of greenhouse gas emissions for different fresh food categories. J Clean Prod 140(Part 2):766-783

Davis J, Sonesson U, Baumgartner DU, Nemecek T (2010) Environmental impact of four meals with different protein sources: case studies in Spain and Sweden. Food Res Int 43:1874-1884

De Laurentiis V, Hunt DV, Rogers CD (2016) Overcoming food security challenges within an energy/water/food nexus (ewfn) approach. Sustainability 8:95

DEFRA (2014) The government buying standards for food and catering services. https://www.gov.uk/government/publications/sustainableprocurement-the-gbs-for-food-and-catering-services. Accessed 2 May 2016]

DEFRA (2015) Greenhouse gas conversion factor repository. http:// www.ukconversionfactorscarbonsmart.co.uk/. Accessed April 7 2016

Department for Education (2015) School food in England. Departmental advice for governing bodies. https:/www.gov.uk/government/ publications/standards-for-school-food-in-england. Accessed April 52016

Department of Energy \& Climate Change (2015) Government emission conversion factors for greenhouse gas company reporting: conversion factors 2015-full set

Directorate General for Internal Policies (2015) Freight on road: why EU shippers prefer truck to train. European Union, Brussels

Dodman D (2009) Blaming cities for climate change? An analysis of urban greenhouse gas emissions inventories. Environ Urban 21: 185-201

Ellis T, Gardiner R, Gubbins M, Reese A, Smith D (2015) Aquaculture statistics for the UK, with a focus on England and Wales 2012

Erickson P, Lazarus M, Chandler C, Schultz S (2013) Technologies, policies and measures for GHG abatement at the urban scale. Greenh Gas Measurement Manag 3:37-54

FAO (1995) Code of conduct for responsible fisheries. Food and Agriculture Organization, Rome

FAO (2011) Global food lossess and food waste - extent, causes and prevention. Food and Agriculture Organization, Rome

FAO (2013) FAOSTAT database. Food and Agriculture Organization of the United Nations, Rome

Foley JA, Ramankutty N, Brauman KA, Cassidy ES, Gerber JS, Johnston M, Mueller ND, O'Connell C, Ray DK, West PC, Balzer C, Bennett EM, Carpenter SR, Hill J, Monfreda C, Polasky S, Rockström J, Sheehan J, Siebert S, Tilman D, Zaks DPM (2011) Solutions for a cultivated planet. Nature 478:337-342

Frischknecht R, Steiner R, Jungbluth N (2009) The ecological scarcity method-eco-factors 2006. A method for impact assessment in LCA. Federal Office for the Environment, Bern

Garnett T (2008) Cooking up a storm. Food, greenhouse gas emissions and our changing climate. Food Climate Research Network. Centre for Environmental Strategy, University of Surrey, Guildford

Garnett T (2011) Where are the best opportunities for reducing greenhouse gas emissions in the food system (including the food chain)? Food Policy 36:S23-S32

Haroun D et al (2009) Primary school food survey. School Food Trust, Sheffield, p 2009

Haroun D, Harper C, Wood L, Nelson M (2011) The impact of the foodbased and nutrient-based standards on lunchtime food and drink provision and consumption in primary schools in England. Public Health Nutr 14:209-218
Hess T, Andersson U, Mena C, Williams A (2015) The impact of healthier dietary scenarios on the global blue water scarcity footprint of food consumption in the UK. Food Policy 50:1-10

HMRC (2013) Overseas trade statistics. www.uktradeinfo.com. Accessed Nov 182016

Hoekstra AY (2003) Virtual water: an introduction. IHE-Delft, Delft

Hoekstra AY, Chapagain AK (2006) Water footprints of nations: water use by people as a function of their consumption pattern. Water Resour Manag 21:35-48

Hoekstra AY, Chapagain AK, Aldaya MM, Mekonnen MM (2009) Water footprint manual: state of the art 2009. Water Footprint Network, Enschede

IPCC (2007) Climate change 2007: the physical science basis. Cambridge and New York

ISO (2006a) ISO 14040 International Standard. International Organization for Standardisation, Geneva

ISO (2006b) ISO 14044 International Standard. International Organization of Standardization, Geneva

ISO (2013) ISO 14067 International Standard. International Organization of Standardization, Geneva, Swizerland

ISO (2014) ISO 14046 International Standard. International Organization for Standardization, Geneva

Jefferies D, Muñoz I, Hodges J, King VJ, Aldaya M, Ercin AE, Milà i Canals L, Hoekstra AY (2012) Water footprint and life cycle assessment as approaches to assess potential impacts of products on water consumption. Key learning points from pilot studies on tea and margarine. J Clean Prod 33:155-166

Jeswani HK, Azapagic A (2011) Water footprint: methodologies and a case study for assessing the impacts of water use. J Clean Prod 19: 1288-1299

Jungbluth N, Keller R, König A (2016) ONE TWO WE-life cycle management in canteens together with suppliers, customers and guests. Int J Life Cycle Assess 21:646-653

Kendall A, Brodt SB (2016) Comparing alternative nutritional functional units for expressing life cycle greenhouse gas emissions in food production systems In: 10th International Conference on Life Cycle Assessment of Food, Dublin, 2016

Larsen HN, Hertwich EG (2009) The case for consumption-based accounting of greenhouse gas emissions to promote local climate action. Environ Sci Pol 12:791-798

Lee SE, Quinn AD, Rogers CD (2016) Advancing city sustainability via its systems of flows: the urban metabolism of Birmingham and its hinterland. Sustainability 8:220

Low Carbon Oxford (2012) Food printing Oxford: how to feed a city. Oxford

Mairie de Paris (2007) Paris climate protection plan. http://www.energycities.eu/IMG/pdf/Paris_climate_protection_plan_2007.pdf. Accessed March 302017

Mekonnen MM, Hoekstra AY (2010a) The green, blue and grey water footprint of crops and derived crop products. UNESCO-IHE, Delft

Mekonnen MM, Hoekstra AY (2010b) The green, blue and grey water footprint of farm animals and animal products. UNESCO-IHE, Delft

Milà I, Canals L, Chenoweth J, Chapagain A, Orr S, Antón A, Clift R (2009) Assessing freshwater use impacts in LCA: part I - inventory modelling and characterisation factors for the main impact pathways. Int J Life Cycle Assess 14:28-42

Morgan K, Sonnino R (2007) Empowering consumers: the creative procurement of school meals in Italy and the UK. Int J Consum Stud 31: $19-25$

Munksgaard J, Pedersen KA (2001) CO 2 accounts for open economies: producer or consumer responsibility? Energy Policy 29:327-334

OECD (2012) The OECD environmental outlook to 2050. Key findings on climate change. http://www.oecd.org/env/cc/Outlook\%20to\% 202050_Climate\%20Change\%20Chapter_HIGLIGHTS-FINA8pager-UPDATED\%20NOV2012.pdf. Accessed Jan 172017 
O'Keefe L, McLachlan C, Gough C, Mander S, Bows-Larkin, A (2016) Consumer responses to a future UK food system. Brit Food J 118: 412-428

Pahlow M, van Oel PR, Mekonnen MM, Hoekstra AY (2015) Increasing pressure on freshwater resources due to terrestrial feed ingredients for aquaculture production. Sci Total Environ 536:847-857

Peters GP (2008) From production-based to consumption-based national emission inventories. Ecol Econ 65:13-23

Peters GP, Hertwich EG (2007) Post-Kyoto greenhouse gas inventories: production versus consumption. Clim Chang 86:51-66

Peters GP, Minx JC, Weber CL, Edenhofer O (2011) Growth in emission transfers via international trade from 1990 to 2008. Proc Natl Acad Sci U S A 108:8903-8908

Pfister S, Koehler A, Hellweg S (2009) Assessing the environmental impacts of freshwater consumption in LCA. Environ Sci Technol 43:4098-4104

Pothukuchi K, Kaufman LJ (1999) Placing the food system on the urban agenda: the role of municipal institutions in food systems planning. Agric Hum Values 16:213-224

Public Health England (2015) McCance and Widdowson's composition of foods integrated dataset. https://www.gov.uk/government/ publications/composition-of-foods-integrated-dataset-cofid. Accessed Dec 22017

Quested T, Ingle R, Parry A (2012) Household food and drink waste in the United Kingdom 2012. WRAP, London

Ramaswami A, Hillman T, Janson B, Reiner M, Thomas G (2008) A demand-centered, hybrid life-cycle methodology for city-scale greenhouse gas inventories

Ribal J, Fenollosa ML, García-Segovia P, Clemente G, Escobar N, Sanjuán N (2016) Designing healthy, climate friendly and affordable school lunches. Int J Life Cycle Assess 21:631-645

Riddlestone S, Plowman J (2009) Capital consumption; the transition to sustainable consumption and production in London. Bioregional and London Sustainable Development Commission

Ridoutt BG, Pfister S (2010) A revised approach to water footprinting to make transparent the impacts of consumption and production on global freshwater scarcity. Glob Environ Chang 20:113-120

Ridoutt BG, Eady SJ, Sellahewa J, Simons L, Bektash R (2009) Water footprinting at the product brand level: case study and future challenges. J Clean Prod 17:1228-1235

Saarinen M, Kurppa S, Virtanen Y, Usva K, Mäkelä J, Nissinen A (2012) Life cycle assessment approach to the impact of home-made, readyto-eat and school lunches on climate and eutrophication. J Clean Prod 28:177-186
San Francisco Department of the Environment (2013) San Francisco climate action strategy. 2013 Update. https://sfenvironment.org/ sites/default/files/engagement_files/sfe_cc ClimateActionStrategyUpdate2013.pdf. Accessed March 302017

Silvenius F, Grönman K, Katajajuuri J-M, Soukka R, Koivupuro H-K, Virtanen Y (2014) The role of household food waste in comparing environmental impacts of packaging alternatives. Packag Technol Sci 27:277-292

Sonesson U, Mattsson B, Nybrant T, Ohlsson T (2005) Industrial processing versus home cooking: an environmental comparison between three ways to prepare a meal. Ambio 34:414-421

Sonnino R, McWilliam S (2011) Food waste, catering practices and public procurement: a case study of hospital food systems in Wales. Food Policy 36:823-829

Strasburg VJ, Jahno VD (2015) Sustentabilidade de cardápio: avaliação da pegada hídrica nas refeições de um restaurante universitário. Rev Ambiente Agua 10:903-914

Teixeira RFM (2015) Critical appraisal of life cycle impact assessment databases for agri-food materials. J Ind Ecol 19:38-50

The School Food Plan (2015) What works well recipe hub. http:// whatworkswell.schoolfoodplan.com/articles/category/52/recipesmenus. Accessed 16th Nov 2016

UNFCCC (1997) Kyoto protocol. http://unfccc.int/kyoto protocol/items/ 2830.php. Accessed Nov 272013

UNFPA (2014) Urbanization: a majority in cities. http://www.unfpa.org/ pds/urbanization.htm. Accessed March 262017

van Dooren C (2016) Proposing the nutrient density unit as the functional unit in LCAs of foods. In: 10th International Conference on Life Cycle Assessment of Food, Dublin, 2016

van Oel PR, Mekonnen MM, Hoekstra AY (2009) The external water footprint of the Netherlands: geographically-explicit quantification and impact assessment. Ecol Econ 69:82-92

Vanham D, Mekonnen MM, Hoekstra AY (2013) The water footprint of the EU for different diets. Ecol Indic 32:1-8

Vanham D, Del Pozo S, Pekcan AG, Keinan-Boker L, Trichopoulou A, Gawlik BM (2016) Water consumption related to different diets in Mediterranean cities. Sci Total Environ 573:96-105

Virtanen Y, Kurppa S, Saarinen M, Katajajuuri JM, Usva K, Mäenpää I, Mäkelä J, Grönroos J, Nissinen A (2011) Carbon footprint of foodapproaches from national input-output statistics and a LCA of a food portion. J Clean Prod 19:1849-1856

Wood FR, Dawkins E, Bows-Larkin A, Barrett J (2014) Applying ImPACT: a modelling framework to explore the role of producers and consumers in reducing emissions. Carbon Manage 5:215-231 